\title{
Meeting the need: The Hospitality Training Program of the Palm Beaches
}

\author{
Elsa DeGoias*, Laurie Cruz and Eric Freilich \\ CareerSource Palm Beach County, West Palm Beach, FL, USA
}

\begin{abstract}
.
BACKGROUND: The Hospitality Training Program of the Palm Beaches was developed to teach the fundamentals of hotel and lodging operations, soft skills, and job readiness methods to individuals with disabilities. The program blends classroombased and hands-on instruction to create an engaging and interactive learning environment for participants. Graduates earn industry certifications from The American Hotel and Lodging Association in areas that include Guest Service, Guestroom Attendant, and Maintenance.

OBJECTIVE: The article describes CareerSource Palm Beach County's launch, growth, and success of the Hospitality Training Program of the Palm Beaches to meet the demands and needs of employers in the Hospitality industry, one of the county's most in-demand employers.
\end{abstract}

Keywords: Hospitality, vocational training, career readiness, disabilities

\section{Introduction}

According to the U.S. Bureau of Labor Statistics (2018), the unemployment rate in Palm Beach County as of October 2018 was 3.1\%, a 12-year low. Nationwide, and similarly in Palm Beach County, the rate is approximately twice that rate for individuals with disabilities as they face unique challenges obtaining and maintaining employment (US Department of Labor, 2018). Factors that may contribute to this gap include a deficiency of employer education and uncertainty of the rules and regulations that apply to hiring individuals with disabilities. Once employers overcome the misconceptions associated with this diverse workforce, they often find that hiring and retaining individuals with disabilities helps build a diverse workforce and increases the overall morale in the workplace.

*Address for correspondence: Elsa DeGoias $\quad$ EdD, 3400 Belvedere Road, West Palm Beach, FL 33406, USA. Tel.: +1 561 3401060 /Ex2602; E-mail: edegoias@ careersourcepbc.com.
One industry in Palm Beach County that employs a diverse population and has numerous positions available throughout the year is Hospitality. This industry sector had the second fastest annual job growth rate compared to all metro areas in Florida with an $8.6 \%$ increase in new jobs from October 2017 to October 2018 in Palm Beach County for a total 191,100 jobs. This year, the Sun Sentinel noted that, "Palm Beach County's hotel occupancy rate reached a three-year high in March ... [with] visitors fill[ing] 88.6 percent of Palm Beach County's available hotel rooms" (Hurtibise, 2018). To help meet the industry's demand for qualified individuals to fill these roles, CareerSource Palm Beach County developed The Hospitality Training Program of the Palm Beaches to teach the fundamentals of hotel and lodging operations, soft skills, and job readiness methods to individuals with disabilities. The program blends classroom-based and hands-on instruction to create an engaging and interactive learning environment for participants. Graduates earn national industry certifications from The American Hotel and Lodging 
Association in areas that include Guest Service, Guestroom Attendant, and Maintenance.

\section{Program launch and growth}

The pilot class of the Hospitality Training Program of the Palm Beaches was launched in the fall of 2016 with the support of CareerSource Palm Beach County's senior leadership. With the framework and funding in place, CSPBC's Disability Services and Ticket to Work staff began recruiting for the first class that was composed of students from the Disability Services, Supplemental Nutrition Assistance Program (SNAP), and Temporary Assistance for Needy Families (TANF) departments.

The two-level screening process for recruiting consisted of a telephone and in-person interview to determine if the student met the basic criteria for the program, level of competency and interest the student had in working of hospitality. The students were also given the Best Work Data skills assessment and strength identifier, a 25-minute online experience that measures the traits and abilities that determine how a person thinks, learns and behaves. The importance for our students and clients is that these same factors determine how a person delivers specific job behaviors and if they are a good fit for the hospitality industry so we can then match our students with jobs based on their strengths and abilities. Students take home a report depicting strengths to assist them with their job endeavors after graduation.

After the recruitment and assessment process students were ready to start their hospitality training, Disability Services Manager Dr. Elsa DeGoias and Senior career consultant Eric Freilich facilitated the class which was held at Children's Services Council of Palm Beach County in Boynton Beach, Florida. In addition to the core curriculum, an art instructor taught a creative component where the students created original artwork based on the theme of hospitality. This provided students a chance to express their creativity while applying the fundamentals they learned in class.

Additional support came from a career consultant who connected Dr. DeGoias with The Colony Palm Beach, an upscale hotel on Palm Beach Island. The Colony Palm Beach opened their doors to the students to provide hands-on training. They were eager to learn about the Colony's housekeeping operations and were trained by their staff on the intricate details of how to prepare a guestroom to the hotel's standards. Back in the classroom, students also used the Virtual Interactive Training Agent (ViTA) software from the Dan Marino Foundation, which creates a virtual environment where students take part in mock interviews with interactive avatars to practice and refine their job interviewing skills.

The weeks quickly progressed with students immersed in engaging lectures, guest speakers, and hands-on experiences. It was soon time for them to take the American Hotel and Lodging Association exams in Guest Service and Guestroom Attendant, and $100 \%$ of the class passed and received their certificates and pins from the organization. Many of the students were employed shortly after graduation and began applying the knowledge and skills they learned in class.

The instructors had little time before the next class, which was again composed of students from multiple programs. Building upon the success of the previous class, the program continued to grow with students receiving a first-hand look at the Hospitality industry from the Hyatt Place West Palm Beach/Downtown and the Hilton Garden Inn Palm Beach Gardens. While onsite, participants received a behind-the-scenes tour of the facilities to learn more about the keys to success in the Hospitality field. Guest speakers from the Eau Palm Beach Resort $\&$ Spa also shared their experience and knowledge with the students. The class again contained creative aspect; this time on photography. As with the previous class, several students were employed soon after graduation.

\section{Early expansion}

Early in 2018, CareerSource Palm Beach County was awarded the Pathways to Prosperity for LowIncome Floridians grant by the state of Florida for the purpose of expanding the Hospitality training to participants from additional local and federal programs. The funding provided the organization the opportunity to purchase new equipment and software for students, including an online portal for instructors to communicate with students, parents, and our case managers along with interactive hotel simulation software and a third certification in Maintenance from the American Hotel and Lodging Association.

As part of the grant, CareerSource Palm Beach County built upon their existing partnership with Gulfstream Goodwill Industries who provided inkind classroom space and assisted with recruiting 
and placing students in the class. The new certification in Maintenance provided students with a range of knowledge on topics from how to change an air conditioner filter to diagnosing and repairing a generator. Instructors used a combination of diagrams and videos to illustrate the topics, and the students were deeply engrossed in learning the intricate details of maintenance work.

They also received training in financial literacy using curriculum developed by the FDIC MoneySmart for Adults program. The program "is a comprehensive financial education curriculum designed to help low and moderate income individuals outside the financial mainstream enhance their financial skills and create positive banking relationships" (2018). It educates consumers on topics such as banking basics, establishing and repairing credit, and home ownership. The program encompassed these and other strategies to help students effectively manage their finances as they prepared to enter or re-enter the workforce.

\section{Closing the digital divide}

Another key component of the Hospitality Training Program of the Palm Beaches is addressing digital literacy to decrease the digital divide among its diverse student population. According to a 2013 study conducted by the Pew Research Center, " $32 \%$ of non [internet]-users said the internet was too difficult to use, including $8 \%$ of this group who said they were "too old to learn"' (Anderson, Perrin, \& Jiang). Additionally, they noted "internet non-adoption is correlated to a number of demographic variables, including age, educational attainment, household income and community type" (Anderson, Perrin, \& Jiang, 2018).

This is pertinent to the program's goals to increase independence and self-sufficiency among individuals with unique challenges to obtaining employment. By expanding their technical skills through interactive lessons on programs such as Microsoft Excel, PowerPoint, and Word, they can make strides towards job readiness when preparing resumes and cover letters (Word), creating and maintaining a budget (Excel) and creating unique ways to present their accomplishments and skills to potential employers (PowerPoint).

A 2017 article by Capella University stresses the importance of integrating technology, such as the aforementioned programs, into the curriculum. The benefits of doing this include "[encouraging] self-directed learning [to create] an active participant in the learning process; [providing] accommodations for struggling or disabled student[s]; and [reducing] the fear of new technology in the future by familiarizing them with the discovery process for each new tool" ("5 Reasons to Incorporate Technology into Your Classroom").

The role of technology continues to play a key role in expanding the course. In early 2018, CareerSource Palm Beach County added ThinkWave, a cloudbased classroom management system, to deliver electronic content to students in and outside of the classroom. ThinkWave allows the instructors to communicate with their students, parents, and case managers regarding their progress in the class. For students receiving Temporary Assistance for Needy Families (TANF) and Supplemental Nutrition Assistance Program (SNAP) benefits, the attendance module is a helpful tool to ensure compliance to their program(s)' reporting requirements. Additionally, ThinkWave provides the instructor the ability to post content delivered in the course, such as presentations and handouts, along with supplemental materials and links to resources as to maintain compliance with the Americans with Disabilities Act (ADA).

\section{Conquering cultural barriers}

In the summer of 2018, CareerSource PBC launched the Hospitality Training Program of the Palm Beaches in Spanish to reach and include a broader population. The first Spanish class was facilitated by Disability Services Career Consultant and Coach Laurie Cruz. This class included participants from SNAP, TANF and the Refugee Task Force to whom English was a second language. Participants knowledge of the English language ranged from none to some understanding.

CareerSource Palm Beach County built a new partnership with The Youth Co-operative of West Palm Beach who provided in-kind classroom space and assisted with recruiting and referring candidates for the class. A partnership with Catholic Charities was expanded to recruit and include refugees currently receiving services through their agency.

The curriculum was translated and adapted to the Spanish language by Laurie Cruz; an English class (ESL) was added to the curriculum to further enhance the students' knowledge of the English language and to allow them to learn the hospitality terminology that 
would help them secure a position in the hospitality industry. This component was added thanks to the help from ESL volunteers from our partner agency El Sol.

From the first class of graduates, $71 \%$ were placed in full time positions in the industry; of these, $100 \%$ remain employed today. As the second Spanish class prepares to graduate in December of 2018, we are happy to report that $25 \%$ are in the process of securing a job before graduation.

\section{A practical approach}

As noted earlier, the program's longevity and success is built upon a number of innovations. In addition to those previously discussed, the second class of fall 2018 had the unique opportunity to experience the field of hospitality first-hand as their classes were held at a local hotel where they met with employees to learn more about their roles, received a behindthe-scenes tour of the property, and practiced many of the concepts they learned in the classroom. Students were grateful for this opportunity as it took the curriculum into a practical setting and allowed them to explore potential roles in the field. After taking part in the tour, students were further motivated to pursue a career in hospitality and discovered opportunities of which they were not previously aware.

\section{Community partner feedback}

Wildridge, Childs, Cawthra, and Madge (2008) note that " $[w]$ e live in a global society. It is no longer effective for organizations to work alone ... [and] the need for partnership working, often cross-sectoral working or working beyond the boundaries, is recognized as a vital component of success."

Partnerships are recognized as a vital component of success, and can provide significant guidance, support, and accomplishments, such as those we developed with Gulfstream Goodwill Industries and Kolter Hospitality. Partnering with Gulfstream Goodwill Industries allowed the program to grow further as far as student enrollment, placements and handson learning. With our partnership we were provided in-kind classroom space and a hotel simulation room developed by Goodwill Industries, with their furniture donation for our students to practice hands-on learning skills set in the area of room attendant. Goodwill also provided on the job support with collaborative effort both from CareerSource job coaches and Goodwill's for our clients once the student entered the work experience phase of the program. Gulfstream Goodwill Industry's Director of Programs stated that this partnership was a "win for all the growth it has propelled for placements and training is impressive."

The work experience component is possible thanks to our partnership with Kolter Hospitality. Kolter Hospitality specializes in hotel management, development and acquisitions in the hospitality sector. The company has developed a reputable and award-winning portfolio of industry leading hotels in some of Florida's premier destination markets. Kolter Hospitality was built on the foundation of delivering service excellence and superior financial results in our hotels while maintaining an active role in communities. Kolter Hospitality continues to grow with development and acquisition of prime hotels in thriving markets coupled with the retention of best-in-class team members aimed at building guest loyalty and exceeding guest expectations.

Their partnership gave our students experience at their properties after graduating from the program and placing them in jobs after the training period. In addition, now other hotels that have heard about our program's success are reaching out for to us to share our graduates for employment opportunities. The general managers at the Kolter Hospitality Properties are very pleased with our student's certification, level of professionalism and expertise, and they have asked us to continue to provide them with graduates.

\section{Current results}

CareerSource Palm Beach County has seen growth in placing our students in competitive positions in the field of hospitality. Since the start of the program, $50 \%$ of our graduates are currently employed in a number of part-and-full-time positions in the industry. Figure 1 shows the growth in student enrollment from the program's launch in the fall of 2016 through the most recent class of fall 2018. Figure 2 shows the employment rate for program graduates from fall of 2016 through the most recent class of fall 2018. The marginally lower employment rates in spring and summer 2018 is a result of an increase in the number of students participating in the program. As of the date of this article, data are not yet available for current classes. 


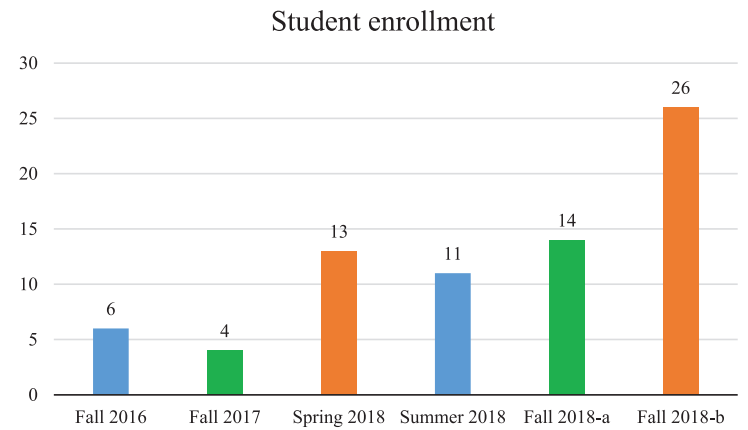

Fig. 1. Enrollment Rates.

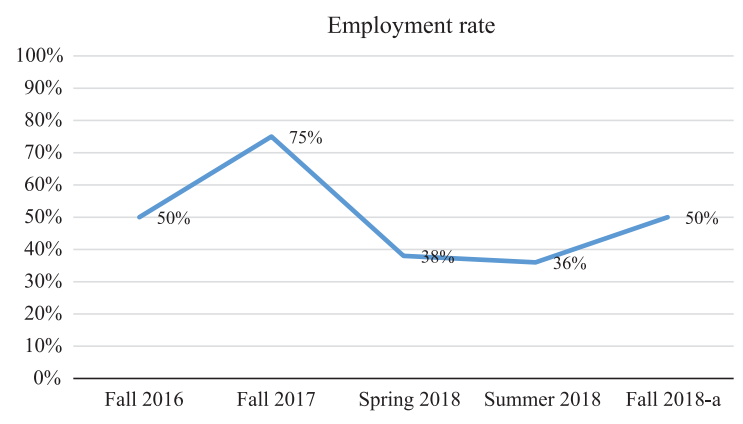

Fig. 2. Employment Rates.

\section{Future of the program}

CareerSource Palm Beach County has presented The Hospitality Training Program of the Palm Beach to these national conferences: the 2017 Workforce Professional Development Summit in Orlando, FL; the 19th Annual Family Café in Orlando, FL, the 2018 Association of People Supporting Employment First (APSE) National Conference in Orlando, FL; and the 2018 National Association of Workforce Development Professionals Conference in Phoenix, AZ.

There is a promising future for the Hospitality Training Program of the Palm Beaches. Funding from the aforementioned Pathways to Prosperity for Low-Income Floridians grant was extended through summer 2019, providing CareerSource Palm Beach County and Gulfstream Goodwill Industries the opportunity to put additional students through the program. We are also collaboratively exploring additional funding streams from organizations such as The Able Trust to ensure the continuation and growth of the program. This will give future students the opportunity to take part in the program and pursue successful careers in the field of hospitality. As Tim Chester (2011) noted, "The focus of entertaining is impressing others; the focus of true hospitality is serving others."

\section{Acknowledgments}

CareerSource Palm Beach County would like to thank their career consultants, community partners, and local employers for supporting The Hospitality Training Program of the Palm Beaches.

\section{Conflict of interest}

None to report.

\section{References}

5 Reasons to Incorporate Technology into Your Classroom. (2017, May 23). Retrieved October 25, 2018 from https://www. capella.edu/blogs/cublog/benefits-of-technology-in-the-class room/

Anderson, M., Perrin, A., \& Jiang, J. (2018). 11\% of Americans don't use the internet. Who are they? Retrieved October 25, 2018 from http://www.pewresearch.org/fact-tank/2018/03/ 05/some-americans-dont-use-the-internet-who-are-they/

Chester, T. (2011). The focus of entertaining is impressing others; the focus of true hospitality is serving others. Retrieved November 27, 2018 from http://kindlequotes.tumblr.com/post/ 10203780620/the-focus-of-entertaining-is-impressing-others

Federal Deposit Insurance Corporation. (2018). Retrieved October 25, 2018, from https://www.fdic.gov/consumers/consumer/ moneysmart/

Hurtibise, R. (2018). Palm Beach County hotel occupancy rate highest in three years. Retrieved August 13, 2018 from http:// www.sun-sentinel.com/business/fl-bz-tricounty-hotel-occupa ncy-bed-tax-march-2018-story.html

Wildridge, V., Childs, S., Cawthra, L., \& Madge, B. (2004). How to create successful partnerships: A review of the literature. Health Information and Libraries Journal, 21(S1), 3-19.

Unemployment Rate in Palm Beach County, FL. (2018). Retrieved from https://fred.stlouisfed.org/series/FLPALM2URN

UNITED STATES DEPARTMENT OF LABOR. (n.d.). Retrieved August 7, 2018 from https://www.dol.gov/odep/ 